Article

\title{
Bioactive Compounds of Cooked Tomato Sauce Modulate Oxidative Stress and Arachidonic Acid Cascade Induced by Oxidized LDL in Macrophage Cultures
}

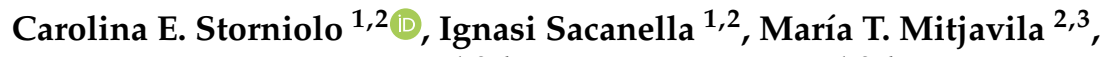 \\ Rosa M. Lamuela-Raventos ${ }^{1,2,4}$ and Juan J. Moreno ${ }^{1,2,4, *}$ \\ 1 Department of Nutrition, Food Sciences and Gastronomy, School of Pharmacy and Food Sciences, University \\ of Barcelona, 08921 Barcelona, Spain \\ 2 Institute of Nutrition and Food Safety (INSA-UB), University of Barcelona, 08921 Barcelona, Spain \\ 3 Department of Immunology, Physiology and Cell Biology, School of Biology, University of Barcelona, \\ 08028 Barcelona, Spain \\ 4 CIBER Fisiopatología de la Obesidad y la Nutrición (CIBEROBN), Instituto de Salud Carlos III, \\ 28029 Madrid, Spain \\ * Correspondence: jjmoreno@ub.edu
}

Received: 18 June 2019; Accepted: 1 August 2019; Published: 13 August 2019

check for updates

\begin{abstract}
Sofrito is a mix of tomato, onion, garlic, and olive oil, which contains phenolic compounds and carotenoids. Consumption of tomato-based sofrito has been related to a lower risk of cardiovascular events, but the mechanisms behind such beneficial effects remain unclear. This study aimed to analyze the effects of representative sofrito compounds such as naringenin, hydroxytyrosol, lycopene, and $\beta$-carotene on mechanisms involved in the pathogenesis of atherosclerosis. We demonstrated that both phenolic compounds and both carotenoids studied were able to inhibit low density lipoproteins (LDL) oxidation, as well as oxidative stress and eicosanoid production induced by oxidized LDL (oxLDL) in macrophage cultures. These effects were not the consequences of disturbing oxLDL uptake by macrophages. Finally, we observed an additive effect of these sofrito compounds, as well as the activity of a main naringenin metabolite, naringenin $7-O-\beta-\mathrm{D}-$ glucuronide on LDL oxidation and oxidative stress.
\end{abstract}

Keywords: tomato; olive oil; superoxide; nitric oxide; prostaglandin $\mathrm{E}_{2}$; leukotriene $\mathrm{B}_{4}$

\section{Introduction}

Epidemiologic and prospective studies have provided strong evidence that a diet rich in a variety of fruits and vegetables, such as the Mediterranean diet, results in a lower risk of developing cardiovascular diseases (CVD) [1-3]. In this way, tomato and tomato-based products have been associated with decreased levels of cardiovascular risk factors [4-6]. However, the bioactive compounds and the mechanisms behind such beneficial effects remain unclear.

Sofrito is not a unique recipe but usually contents a mix of ingredients such as tomato, onion, garlic and olive oil, which contains many bioactive phenolic compounds and carotenoids [7]. Naringenin and chalcone naringenin, a naringenin precursor, are accepted as the main flavonoids in tomatoes and tomato-based sauces [8,9], whereas lycopene and $\beta$-carotene are the more representative carotenoids [7] and hydroxytyrosol appears in sofrito and tomato sauces prepared with olive oil [7]. Interestingly, sofrito has higher levels of bioactive compounds than tomato. Thus, $120 \mathrm{~g}$ of sofrito added to different dishes daily, leads to a total phenolic intake of 15-25 mg and 5-10 mg of carotenoids. Recently, it was 
reported that some of these compounds could modulate oxidative stress and eicosanoid production [10], involved in chronic processes with an important inflammatory component, such as CVD.

The protective beneficial effects of tomato sauces have been mainly attributed to their capacity to prevent atherogenesis by their antioxidant properties $[11,12]$. However, few studies have demonstrated anti-atherogenic effects for narigenin [13] or lycopene [14]. Thus, the action of sofrito bioactive compounds on the main mechanisms involved in CVD remains to be investigated. Low-density lipoproteins (LDL) oxidation is an early and critical event in atherogenesis $[15,16]$. However, high levels of oxidized LDL (oxLDL) correlate with the severity of CVD [17], and oxLDL uptake by macrophages promotes the recruitment of leukocytes and accumulation of lipid-laden macrophages named foam cells [18], which are the most predominant cell type in the fatty streaks [19].

Considering the above mentioned observations, we aimed to study the effect of compounds found in sofrito on oxidation of LDL, as well as on oxidative stress and eicosanoid production by macrophages incubated in the presence of oxLDL, important events implicated in the pathogenesis of atherosclerosis.

\section{Materials and Methods}

\subsection{Materials and Chemicals}

Naringenin, lycopene, $\beta$-carotene, hydroxytyrosol, 1,1'-dioctadecyl-3,3,3', $3^{\prime}$ tetra-methylindocarbocyanine perchlorate (Dil), p-nitro blue tetrazolium (NBT), phorbol myristate-acetate (PMA), superoxide dismutase (SOD), catalase, and fucoidan were obtained from Sigma Chemical Co. (St. Louis, MO, USA). Naringenin 7-O- $\beta$-D-glucuronide was obtained from Cayman Chem. Co. (Ann Arbor, MI, USA). Cell culture medium, foetal bovine serum and supplements were obtained from GE Healthcare Hyclone (Logan, UT, USA). All other reagents were of analytical grade. Assayed compounds were dissolved in dimethylsulfoxide (DMSO) and the final concentration of DMSO in cell cultures was lower than $0.1 \%$.

\subsection{Culture of Human Monocyte/Macrophage}

Human monocyte cell line THP-1 was obtained from American Type Culture Collection (ATCC, Manassas, VA, USA). The cells were maintained at a maximal density of $1 \times 10^{6}$ cells $/ \mathrm{mL}$ in RPMI 1640 medium containing $10 \%$ fetal bovine serum and $1 \%$ penicillin/streptomycin solution at $37{ }^{\circ} \mathrm{C}$ in a $5 \% \mathrm{CO}_{2}$ incubation. To induce macrophage differentiation, THP-1 cell $\left(1 \times 10^{5}\right.$ cells/well $)$ were incubated in multi-well plates in the presence of $100 \mathrm{nM}$ PMA for $48 \mathrm{~h}$ to complete the morphological and biochemical differentiation to macrophages [20].

\subsection{Isolation of $L D L$ and $L D L$ Oxidation Assay}

LDL (density 1.03-1.053) were prepared by sequential ultracentrifugation from pooled, citrated human plasma from six healthy normolipidemic volunteers (personnel of the laboratory), according to the method of Chung et al. [21]. Finally, LDL were dialysed, filtered through a $0.45 \mu \mathrm{M}$ filter and stored at $4{ }^{\circ} \mathrm{C}$. The protein concentration was determined by the Lowry method modified by Peterson [22].

LDL were diluted with PBS to a final concentration of $50 \mu \mathrm{g}$ protein $/ \mathrm{mL}$ and incubated at $37^{\circ} \mathrm{C}$ with freshly prepared $\mathrm{CuSO}_{4} \cdot 5 \mathrm{H}_{2} \mathrm{O}(2.5 \mu \mathrm{M})$ in the presence of the tested compounds. Conjugated dienes $(\mathrm{CD})$ were monitored spectrophotometrically $(234 \mathrm{~nm})$ every $5 \mathrm{~min}$ as described by Esterbauer et al. [23] and thiobarbituric acid reactive substances (TBARs) measured fluorimetrically (excitation at $515 \mathrm{~nm}$ and emission at $553 \mathrm{~nm}$ ) according to the method described by Yagi [24].

\subsection{Assay for Binding and/or Uptake of oxLDL by Macrophages}

In order to elucidate whether the effects observed were a consequence of disturbing oxLDL uptake by macrophages, oxLDL were labelled using the fluorescent probe Dil according to the methodology described by Innerarity et al. [25]. Thus, oxLDL ( $1 \mathrm{mg}$ protein/mL) were incubated overnight with Dil $(30 \mu \mathrm{g} / \mathrm{mL})$ at $37^{\circ} \mathrm{C}$ and, finally, Dil-labelled oxLDL were isolated by ultracentrifugation. The medium 
was removed and macrophages were incubated in the presence of studied compounds and finally Dil-labelled oxLDL (50 $\mu \mathrm{g}$ protein/mL) or unlabelled oxLDL (50 $\mu$ g protein $/ \mathrm{mL}$ ) were incubated for $3 \mathrm{~h}$. After being washed three times with PBS, cells were lysed with $0.1 \mathrm{M} \mathrm{NaOH}$, and the solution was neutralised with $0.1 \mathrm{M} \mathrm{HCl}$. Fluorescence intensity was measured with a spectrofluorometer (excitation at $524 \mathrm{~nm}$ and emission at $567 \mathrm{~nm}$ ) [26].

\subsection{Determination of Reactive Oxygen Species (ROS) and Nitric Oxide (NO) Production}

The medium was removed from macrophage cultures, which were incubated with the testing compounds for $30 \mathrm{~min}$ and then stimulated with oxLDL (50 $\mu \mathrm{g}$ protein/mL) for $30 \mathrm{~min}$. Superoxide anion $\left(\mathrm{O}_{2}{ }^{-}\right)$generation was determined in aliquots of culture supernatant by measuring the superoxide dismutase-inhibitable reduction of NBT [27]. Nitrite $\left(\mathrm{NO}_{2}{ }^{-}\right)$accumulation in the cell-free medium, an indicator of NO production, was measured using the Griess reagent as we described previously [27].

\subsection{Measurement of Prostaglandin $E_{2}\left(P G E_{2}\right)$ and Leukotriene $B_{4}\left(L_{T B}\right)$}

The medium of macrophage cultures was removed and testing compounds were incubated for $30 \mathrm{~min}$, and then macrophages were stimulated with oxLDL (50 $\mu \mathrm{g}$ protein $/ \mathrm{mL})$ for $30 \mathrm{~min}$. An aliquot of culture medium $(0.25 \mathrm{~mL})$ was acidified with $1 \mathrm{~mL}$ of $1 \%$ formic acid. $\mathrm{PGE}_{2}$ or $\mathrm{LTB}_{4}$ was extracted in ethyl acetate $(5 \mathrm{~mL})$ and, after discarding the aqueous phase, the organic phase was evaporated under a stream of nitrogen. $\mathrm{PGE}_{2}$ and $\mathrm{LTB}_{4}$ levels were determined using monoclonal enzyme immunoassay kits (Cayman Chemical Co., Ann Arbor, MI, USA) following the manufacturer's protocol.

\subsection{Statistical Analysis}

Results are expressed as mean \pm SEM. Differences between control and treated samples were tested using either Student's $t$-test or one-way analysis of variance, followed by the least significant differences test when appropriate differences were considered statistically significant at $p<0.05$.

\section{Results}

\subsection{Sofrito Compounds Modulate LDL Oxidation Induced by $\mathrm{Cu}^{2+}$}

To mimic in vivo conditions, pooled plasma was preincubated with the compounds under study at $37^{\circ} \mathrm{C}$ for $1 \mathrm{~h}$. LDL were subsequently isolated and its resistance to oxidation induced by $\mathrm{Cu}_{2} \mathrm{SO}_{4}$ tested. $\mathrm{CD}$ and TBARs production were reduced by the presence of bioactive compounds, and hydroxytyrosol and naringenin being more effective than lycopene or $\beta$-carotene (Table 1 ). Our results show an additive effect of these compounds at $1 \mu \mathrm{M}$ that was able to delay LDL oxidation. 
Table 1. Effect of sofrito bioactive compounds of on $\mathrm{Cu}^{2+}$ mediated oxidation of low-density lipoproteins LDL, which was monitored by conjugated dienes (CD) and thiobarbituric acid reactive substances (TBARs) formation. $\mathrm{T}_{\text {lag }}$ was the difference in lag phase (min) between $\mathrm{Cu}^{2+}$ and $\mathrm{Cu}^{2+}$ plus tested compounds. $\Delta \mathrm{T}_{\text {lag }}(\%)=$ sample $\mathrm{T}_{\text {lag }}-$ control $\mathrm{T}_{\text {lag }} /$ control $\mathrm{T}_{\text {lag }}(\times 100)$. MDA is expressed as $\mathrm{nmol} / \mathrm{mg}$ of LDL protein. Superoxide dismutase (SOD) $(30 \mu \mathrm{M})$ and catalase $(50 \mu \mathrm{M})$ were used as positive control. Results are expressed as means \pm SEM of two experiments performed in triplicate. * Significantly different from $\mathrm{Cu}^{2+}$ without treatments.

\begin{tabular}{|c|c|c|c|}
\hline & \multicolumn{2}{|c|}{ CD } & \multirow{2}{*}{$\begin{array}{c}\text { TBARs } \\
\text { MDA }\end{array}$} \\
\hline & $\mathrm{T}_{\text {lag }}(\min )$ & $\Delta \mathrm{T}_{\operatorname{lag}}(\%)$ & \\
\hline LDL & & & $3.2 \pm 0.2$ \\
\hline $\mathrm{LDL}+\mathrm{Cu}^{2+}$ & $58 \pm 6$ & & $27.3 \pm 1.3$ \\
\hline $\mathrm{LDL}+\mathrm{Cu}^{2+}+$ Naringenin $(1 \mu \mathrm{M})$ & $97 \pm 7 *$ & 67.2 & $19.5 \pm 0.7 *$ \\
\hline $\mathrm{LDL}+\mathrm{Cu}^{2+}+$ Naringenin $(10 \mu \mathrm{M})$ & $198 \pm 13 *$ & 241.4 & $12.1 \pm 0.4$ * \\
\hline $\mathrm{LDL}+\mathrm{Cu}^{2+}+$ Naringenin Gluc. $(10 \mu \mathrm{M})$ & $204 \pm 12 *$ & 251.7 & $13.6 \pm 0.3$ * \\
\hline $\mathrm{LDL}+\mathrm{Cu}^{2+}+$ Hydroxytyrosol $(1 \mu \mathrm{M})$ & $225 \pm 11 *$ & 287.9 & $14.8 \pm 0.3$ * \\
\hline $\mathrm{LDL}+\mathrm{Cu}^{2+}+$ Hydroxytyrosol $(10 \mu \mathrm{M})$ & $>500 *$ & & $8.3 \pm 0.2 *$ \\
\hline $\mathrm{LDL}+\mathrm{Cu}^{2+}+$ Lycopene $(10 \mu \mathrm{M})$ & $73 \pm 6$ & 25.8 & $22.5 \pm 0.4$ \\
\hline $\mathrm{LDL}+\mathrm{Cu}^{2+}+$ Lycopene $(50 \mu \mathrm{M})$ & $121 \pm 8^{*}$ & 108.6 & $15.7 \pm 0.3$ * \\
\hline $\mathrm{LDL}+\mathrm{Cu}^{2+}+\beta$ Carotene $(10 \mu \mathrm{M})$ & $72 \pm 5$ & 24.1 & $23.8 \pm 0.4$ \\
\hline $\mathrm{LDL}+\mathrm{Cu}^{2+}+\beta$ Carotene $(50 \mu \mathrm{M})$ & $119 \pm 7 *$ & 105.2 & $17.9 \pm 0.3 *$ \\
\hline $\mathrm{LDL}+\mathrm{Cu}^{2+}+$ all compounds $(1 \mu \mathrm{M})$ & $386 \pm 8 *$ & 565.5 & $10.6 \pm 0.2 *$ \\
\hline $\mathrm{LDL}+\mathrm{Cu}^{2+}+\mathrm{SOD}+$ Catalase & $>500 *$ & & $5.7 \pm 0.2 *$ \\
\hline
\end{tabular}

Bioactive compound concentrations was chosen considering the plasma and tissue levels reached after sofrito ingestion [8].

\subsection{Phenolic Compounds and Carotenoids of Sofrito Reduce Oxidative Stress and Eicosanoid Synthesis Induced by $0 x L D L$}

OxLDL (50 $\mu \mathrm{g}$ protein/mL) induced $\mathrm{O}_{2}{ }^{-}$and $\mathrm{NO}_{2}{ }^{-}$formation with maximum levels reached 30 min after macrophages stimulation (Table 2). We observed no cell toxicity using this range of concentration of oxLDL and the exogenous addition of superoxide dismutase (SOD) or catalase inhibited oxidative stress induced by oxLDL in these experimental conditions (data not shown). Furthermore, we observed that oxLDL were able to induce cyclooxygenase and 5-lipoxygenase pathways reflected in the enhancement of $\mathrm{PGE}_{2}$ and $\mathrm{LTB}_{4}$ synthesis in macrophage cultures (Table 2).

Table 2. Effects of naringenin and naringenin 7-O- $\beta$-D-glucuronide on reactive oxygen species (ROS), $\mathrm{NO}), \mathrm{PGE}_{2}$ and leukotriene $\mathrm{B}_{4}\left(\mathrm{LTB}_{4}\right)$ production by macrophages in the presence of oxidized LDLs (oxLDLs). ROS are expressed as $\mathrm{O}_{2}^{-}(\mathrm{nmol} / \mathrm{mL}), \mathrm{NO}$ was indirectly determined as $\mathrm{NO}_{2}^{-}(\mathrm{nmol} / \mathrm{mL})$, and $\mathrm{PGE}_{2}$ and $\mathrm{LTB}_{4}$ concentration in cell culture supernatant were expressed as $\mathrm{pg} / \mathrm{mL}$. Naringenin and naringenin $7-O-\beta$-D-glucuronide $(10 \mu \mathrm{M})$ were incubated for $30 \mathrm{~min}$ and then stimulated with oxLDL for $30 \mathrm{~min}$ a $37^{\circ} \mathrm{C}$. Data are the means \pm SEM. of three experiments performed in triplicate. ${ }^{*} p<0.05$ versus control, ${ }^{\neq} p<0.05$ versus non-treated cells.

\begin{tabular}{lcccc}
\hline & ROS & NO & PGE $_{2}$ & LTB $_{4}$ \\
\hline Control & $2.0 \pm 0.1$ & $1.3 \pm 0.1$ & $2.5 \pm 0.5$ & $1.8 \pm 0.4$ \\
oxLDL & $15.4 \pm 1.6^{*}$ & $32.1 \pm 2.7^{*}$ & $26.8 \pm 2.6^{*}$ & $21.2 \pm 1.8^{*}$ \\
oxLDL + Naringenin & $6.3 \pm 0.8^{\neq}$ & $12.4 \pm 1.3^{\neq}$ & $11.6 \pm 2.1^{\neq}$ & $13.5 \pm 1.4^{\neq}$ \\
oxLDL + Naringenin 7-O- $\beta$-gluc. & $7.6 \pm 1.2^{\neq}$ & $13.6 \pm 1.5^{\neq}$ & $13.2 \pm 2.5^{\neq}$ & $15.1 \pm 1.3^{\neq}$ \\
\hline
\end{tabular}

The present work shows that naringenin $(0.1-25 \mu \mathrm{M})$, hydroxytyrosol $(0.1-10 \mu \mathrm{M})$, lycopene $(1-50 \mu \mathrm{M})$, and $\beta$-carotene $(1-50 \mu \mathrm{M})$ decreased in a concentration-dependent manner the production of $\mathrm{O}_{2}{ }^{-}$and $\mathrm{NO}_{2}{ }^{-}$produced by oxLDL stimulated macrophages, as indicators of ROS and NO production, 
respectively (Figure 1). In a similar form, these compounds decreased the oxLDL induced biosynthesis of eicosanoids representative of cyclooxygenase and 5-lipoxygenase pathways such as PGE $\mathrm{Pand} \mathrm{LTB}_{4}$, respectively (Figure 2).
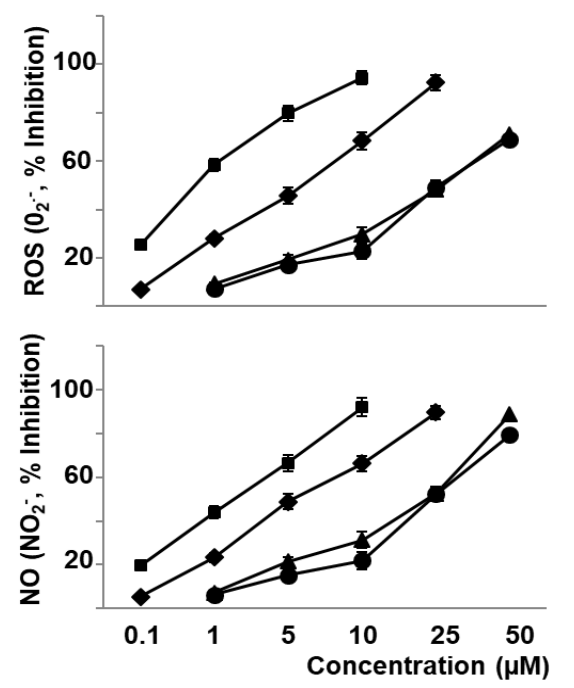

Figure 1. Effect of bioactive compounds of sofrito on $\mathrm{O}_{2}{ }^{-}$and $\mathrm{NO}_{2}{ }^{-}$production stimulated by oxLDL. Macrophages were incubated with naringenin $(\bullet)$, hydroxytyrosol $(\boldsymbol{\bullet})$, lycopene $(\boldsymbol{\Delta})$, or $\beta$-carotene $(\bullet)$ for $30 \mathrm{~min}$, and then stimulated with oxLDL $(50 \mu \mathrm{g}$ protein $/ \mathrm{mL})$ for $30 \mathrm{~min}$. Finally, $\mathrm{O}_{2}{ }^{-}$and $\mathrm{NO}_{2}{ }^{-}$ were measured. Data are the means \pm SEM of three experiments performed in triplicate.
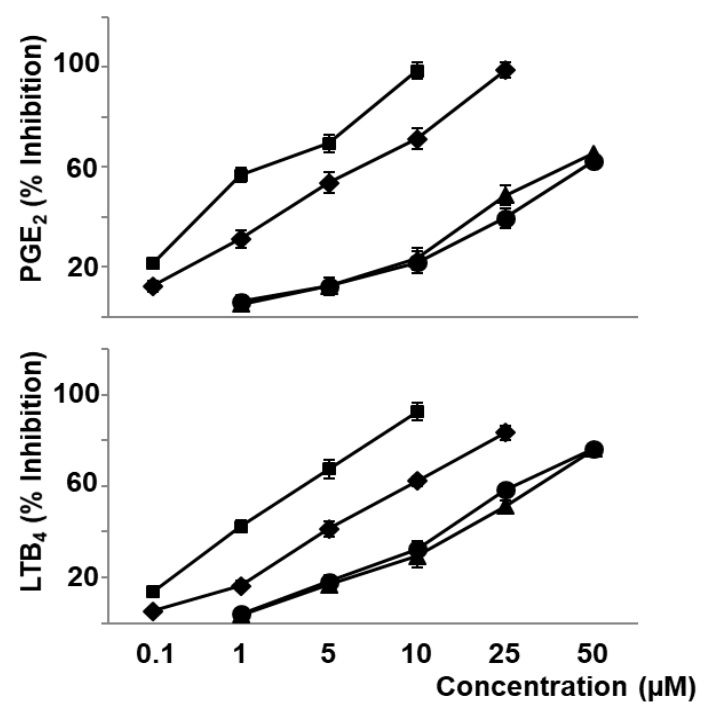

Figure 2. Effect of bioactive compounds of sofrito on prostaglandin $E_{2}$ and leukotriene $B_{4}$ production stimulated by oxLDL. Macrophages were incubated with naringenin $(\boldsymbol{\nabla})$, hydroxytyrosol ( $\mathbf{\square})$, lycopene $(\boldsymbol{\Lambda})$, or $\beta$-carotene $(\bullet)$ for $30 \mathrm{~min}$, and then stimulated with oxLDL $(50 \mu \mathrm{g}$ protein $/ \mathrm{mL})$ for $30 \mathrm{~min}$. Finally, $\mathrm{PGE}_{2}$ or $\mathrm{LTB}_{4}$ were measured. Data are the means \pm SEM of three experiments performed in triplicate.

Interestingly, we did not observe any effect of these compounds on non-stimulated cells (data not shown), but we observed an additive effect of these compounds on $\mathrm{O}_{2}{ }^{-}, \mathrm{PGE}_{2}$, and $\mathrm{LTB}_{4}$ formation induced by oxLDL (Figure 3). 


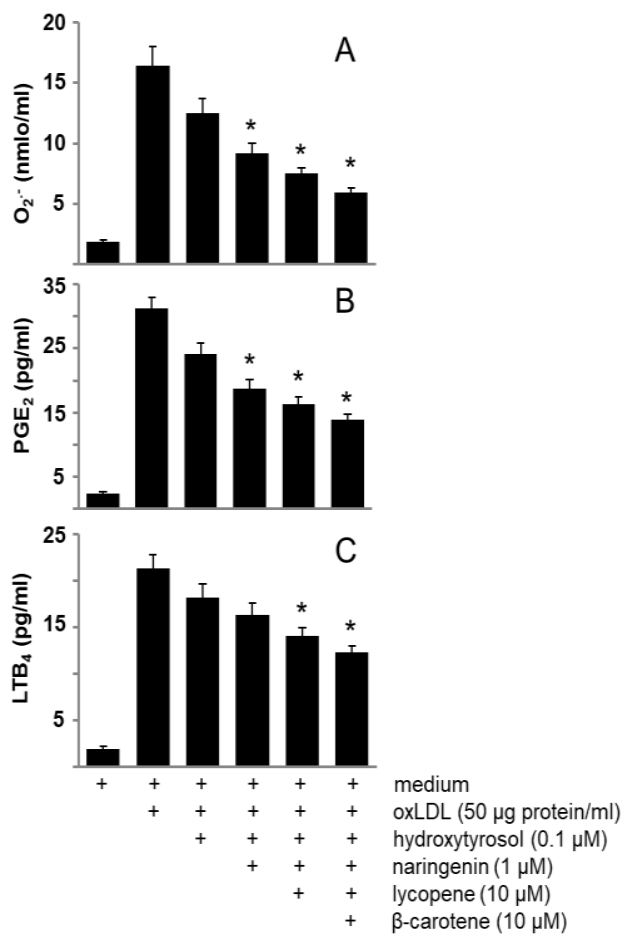

Figure 3. Effects of bioactive compounds of sofrito on $\mathrm{O}_{2}{ }^{-}, \mathrm{PGE}_{2}$ and $\mathrm{LTB}_{4}$ production stimulated by oxLDL. Macrophages were incubated with hydroxytyrosol $(0.1 \mu \mathrm{M})$, naringenin $(1 \mu \mathrm{M})$, lycopene $(10 \mu \mathrm{M})$ or $\beta$-carotene $(10 \mu \mathrm{M})$ for $30 \mathrm{~min}$, and then stimulated with oxLDL (50 $\mu \mathrm{g}$ protein/mL) for $30 \mathrm{~min}$. Finally, $\mathrm{O}_{2}{ }^{-}(\mathbf{A}), \mathrm{PGE}_{2}(\mathbf{B})$ or $\mathrm{LTB}_{4}(\mathbf{C})$ were measured. Data are the means $\pm \mathrm{SEM}$ of three experiments performed in triplicate. * Significantly different $(p<0.05)$ with respect to oxLDL-stimulated macrophages.

\subsection{Phenolic Compounds and Carotenoids of Sofrito Did Not Affect the Binding and Uptake of oxLDL} by Macrophages

We also examined the effects of these compounds found in sofrito on the binding and uptake of oxLDL using Dil-labelled oxLDL. As shown in Table 3, incubation of macrophages with Dil-labelled oxLDL (50 $\mu \mathrm{g}$ protein $/ \mathrm{mL}$ ) resulted in a marked increase in fluorescence intensity, while autofluorescence of the sample prepared from cells stimulated with unlabelled oxLDL, was less than 10 units, findings that demonstrated an oxLDL uptake by macrophages. Under these conditions, naringenin $(10 \mu \mathrm{M})$, hydroxytyrosol $(10 \mu \mathrm{M})$, lycopene $(50 \mu \mathrm{M})$, or $\beta$-carotene $(50 \mu \mathrm{M})$ did not modify fluorescence intensity induced by Dil-labelled oxLDL, whereas fucoidan $(10 \mu \mathrm{g} / \mathrm{mL})$, a polyanionic polysaccharide, effective competitor for oxLDL in studies of receptor binding [28], prevented the increase in fluorescence intensity. Thus, the above effects induced by oxLDL on oxidative stress and eicosanoid production were not consequence of any disturbance of oxLDL binding to macrophages. 
Table 3. Effect of sofrito compounds on binding and/or uptake of Dil-labelled oxLDL. Macrophages were incubated with the compounds for $1 \mathrm{~h}$, and then incubated with Dil-oxLDL $(50 \mu \mathrm{g}$ protein/mL) for $3 \mathrm{~h}$. Then, the cells were washed and lysated and the fluorescence intensity in the lysates were measured. Data are the means \pm SEM of three experiments performed in duplicate. * Significant different from non-treated cells incubated with Dil-oxLDL.

\begin{tabular}{lc}
\hline & Fluorescence Intensity (Arbitrary Units) \\
\hline oxLDL & $21.2 \pm 1.5$ \\
Dil-oxLDL & $532.2 \pm 21.3$ \\
Dil-oxLDL + Naringenin $(10 \mu \mathrm{M})$ & $476.7 \pm 16.1$ \\
Dil-oxLDL + Hydroxytyrosol $(10 \mu \mathrm{M})$ & $453.4 \pm 17.3$ \\
Dil-oxLDL + Lycopene $(50 \mu \mathrm{M})$ & $503.5 \pm 13.8$ \\
Dil-oxLDL + $\beta$-Carotene $(50 \mu \mathrm{M})$ & $517.1 \pm 12.8$ \\
Dil-oxLDL + Fucoidan $(10 \mu \mathrm{g} / \mathrm{mL})$ & $102.6 \pm 3.7$ * \\
\hline
\end{tabular}

3.4. Naringenin 7-O- $\beta$-D-glucuronide Has Similar Activity on Oxidative Stress and Eicosanoid Biosynthesis to Naringenin

Naringenin, once absorbed, is conjugated with sulphates and glucuronides by the enterocytes and transported to the liver where it is also rapidly conjugated as other polyphenols [29]. Hence, it is important to evaluate if naringenin's antioxidant activity and other biological activities are maintained after losing one or more hydroxyl groups of naringenin. Our results show that naringenin 7-O- $\beta$-D-glucuronide inhibits LDL oxidation induced by $\mathrm{Cu}^{2+}$ (Table 1 ) as well as oxidative stress and eicosanoid synthesis induced by oxLDL in a similar extent to naringenin (Table 2).

\section{Discussion}

Atherosclerosis is thought to involve the uptake of oxLDL by macrophages and vascular wall cells [30,31]. The generation of ROS and NO [32], as well as pro-inflammatory mediators such as eicosanoids [33]. Characteristic bioactive compounds of sofrito such as hydroxytyrosol, naringenin, lycopene, and $\beta$-carotene have been demonstrated to be effective as free radical scavengers [34-36]. Thus, the first question addressed by the present study was whether these bioactive compounds present in sofrito were able to modulate LDL oxidation. Our findings demonstrated that both phenolic compounds (hydroxytyrosol and naringenin) and both carotenoids (lycopene and $\beta$-carotene) effectively increased resistance to $\mathrm{Cu}^{2+}$-mediated LDL oxidation, being phenolic compounds more effective than carotenoids. Interestingly, the simultaneous incubation of these compounds at concentrations that can be reached in plasma after sofrito ingestion [37] induced a significant slow/inhibition of LDL oxidation. These findings suggest an important additive and beneficial effect of bioactive sofrito compounds on this event with a pivotal role in early steps of atherogenesis, as was previously reported using lycopene in combination with other bioactive compounds [38].

The present work also shows that exposure to low, non-toxic levels of oxLDL, leads to the production of ROS, NO, and eicosanoids by human macrophages obtained by differentiation of THP-1 monocytes, in agreement with previous results obtained using murine macrophages RAW 264.7 [39]. Interestingly, these effects were observed when we examined an oxLDL concentration capable of transforming macrophages into foam cells [40], a pivotal element in the development of atheroma plaque.

Although several authors reported that olive oil or tomato phenolic compounds and carotenoids modulate LDL oxidation or eicosanoid synthesis using different experimental models, the present study is the first to quantitatively compare the effect of compounds found in sofrito on oxidative stress and eicosanoid synthesis induced by oxLDL in macrophage cultures. The redox state of the cell may act as a molecular switch regulating different genes and enzymes. Previously, we demonstrated that changes of redox state of macrophages stimulated arachidonic acid cascade and consequently the biosynthesis of eicosanoids [41-43]. In this way, Lupo et al. [44] demonstrated that oxLDL induced 
$\mathrm{Ca}^{2+}$-dependent as well as $\mathrm{Ca}^{2+}$-independent phospholipase $\mathrm{A}_{2}$, enzymes involved in arachidonic acid release and consequently in eicosanoid synthesis. Furthermore, Muroya et al. [45] described that oxLDL induced NFKB signalling, a redox-sensitive transcription factor involved in the regulation of cyclooxygenase pathway in macrophages, a pivotal element in $\mathrm{PGE}_{2}$ synthesis. Considered all together, we hypothesized that oxidative stress and eicosanoid synthesis induced by oxLDL can be modulated by the sofrito compound tested. This hypothesis is supported by the fact that naringenin, hydroxytyrosol, lycopene, and $\beta$-carotene were able to inhibit $\mathrm{O}_{2}{ }^{-}, \mathrm{NO}_{2}{ }^{-}, \mathrm{PGE}_{2}$ and $\mathrm{LTB}_{4}$ production induced by oxLDL. Obviously, sofrito is not a unique recipe throughout the Mediterranean countries and consequently the bioactive compound profile can be more diverse. However, the above mentioned compounds can be considered representative of this dish. The more interesting findings of the present study are the additive effects observed when co-incubating macrophages with the phenols and carotenoids tested on the modulation of oxidative stress and eicosanoid synthesis induced by oxLDL. Thus, the simultaneous effects of sofrito bioactive compounds could result in an additional atheroprotective effect. Sofrito preparation involves cooking often at a high temperature that can induce oxidation. However, tomato cooking/processing maintains phenolic content and antioxidant activity [46]. Interestingly, such effects take place at bioactive compound concentrations within the range expected from nutritional intake of sofrito in the context of a Mediterranean type diet [37]. Furthermore, we must consider that these bioactive compounds have been also described to modulate inflammatory elements involved in atherogenesis such as cytokine release and adhesion molecules expression [47]. Other phenolic compounds or carotenoids can also potentially contribute to the above beneficial effects of sofrito on cardiovascular risk factors, especially when sofrito was cooked and enriched with olive oil [47]. Here, our results suggest that the healthy effects of sofrito enriched with olive oil can be, at least in part, a consequence of the presence of extra virgin olive oil rich phenolic compounds such as hydroxytyrosol.

Considering that oxLDL uptake and foam cell formation take place via scavenger receptors [48] and that Miles et al. [49] described that olive oil, a component of sofrito, decreased macrophage uptake of oxLDL though the down regulation of scavenger receptors, we attempted to explore whether sofrito compounds influenced oxLDL interaction with macrophages in our experimental conditions. Our findings demonstrated that the above effects of naringenin, hydroxytyrosol, lycopene, and $\beta$-carotene were not due to interference with oxLDL binding to macrophage receptors. However, we can not exclude that other bioactive compounds of sofrito could have this action. Thus, squalene present in olive oil inhibits oxLDL uptake by macrophages, by reducing CD36 expression whereas tyrosol and hydroxytyrosol did not have this effect [50], findings in agreement with our observations.

The maximum concentrations of naringenin and its metabolites generally appear in 30-60 min after ingestion, and it found conjugated naringenin rather than its free form predominates in the circulation [37]. Consequently, considerable controversy exists as to whether naringenin, or other polyphenols, is an active molecule in vivo as its plasma concentration is in the nanomolar range compared with the micromolar range of its metabolites. Previously, we demonstrated that resveratrol metabolites are antioxidants and have similar biological effects to resveratrol [51]. Our findings demonstrated that naringenin and naringenin 7-O- $\beta$-D-glucuronide, to a similar extent, reduce the oxidative stress and eicosanoid synthesis induced by oxLDL and consequently both molecules may act with additive effects on mechanisms with a central role in atherogenesis.

\section{Conclusions}

Recently, Tresserra-Rimbau and co-workers analysed the most relevant current knowledge of bioactive polyphenols from culinary world to the clinical setting [52]. Here, our findings propose a new molecular mechanism by which bioactive compounds of sofrito, a characteristic ingredient of the Mediterranean diet, may prevent the biosynthesis of pro-inflammatory and pro-atherogenic mediators by oxLDL-stimulated macrophages. Most relevantly, we demonstrated an important additive effect of several sofrito compounds at physiological concentration, which can explain the beneficial effects of cooked tomato sauce, as it was recently reported by Vilahur et al. [53] on coronary endothelial 
function of dyslipidemic animals. Finally, we also observed that naringenin metabolites, which reach higher plasma concentrations than naringenin after oral ingestion, could be active to the same extent as the parent compound. Obviously, additional experimental assays and clinical trials are necessary to confirm the beneficial effects of sofrito inclusion in the diet.

Author Contributions: J.J.M. conceived and designed the experiments, C.E.S. and I.S. performed the experiments, C.E.S., I.S. and J.J.M. analysed the data and wrote the manuscript, and M.T.M. and R.M.L.-R. reviewed the manuscript. All authors have read, reviewed and approved the final version of the manuscript.

Funding: This research was supported by the Spanish Ministry of Economy and Competitivity (AGL2013-49083-C3-1-R and AGL2016-75329R) and by the Autonomous Government of Catalonia (2009SGR0438 and 2014SGR0773).

Conflicts of Interest: None of the authors have any conflict of interest to declare.

\section{References}

1. He, F.J.; Nowson, C.A.; Lucas, M.; MacGregor, G.A. Increased consumption of fruit and vegetables is related to a reduced risk of coronary heart disease: Meta-analysis of cohort studies. J. Hum. Hypertens. 2007, 21, 717-728. [CrossRef] [PubMed]

2. Iqbal, R.; Anad, S.; Ounpuu, S.; Islam, S.; Zhang, X.; Rangarajan, S.; Chifamba, J.; Al-Hinai, A.; Keltai, M. Dietary pattern and the risk of acute myocardial infarction in 52 countries: Results of the interheart study. Circulation 2008, 118, 1929-1937. [CrossRef] [PubMed]

3. Estruch, R.; Ros, E.; Salas-Salvadó, J.; Covas, M.I.; Corella, D.; Arós, F.; Gómez-Gracia, E.; Ruiz-Gutiérrez, V.; Fiol, M.; Lapetra, J.; et al. Primary prevention of cardiovascular disease with a Mediterranean diet. New Engl. J. Med. 2013, 368, 1279-1290. [CrossRef] [PubMed]

4. Cheng, H.M.; Koutsidis, G.; Lodge, J.K.; Ashor, A.; Siervo, M.; Lara, J. Tomato and lycopene supplementation and cardiovascular risk factors: A systematic review and meta-analysis. Atherosclerosis 2017, 257, 100-108. [CrossRef] [PubMed]

5. Salehi, B.; Sharifi-Rad, R.; Sharopov, F.; Namiesnik, J.; Roointan, A.; Kamle, M.; Kumar, P.; Martins, N.; Darifi-Rad, J. Beneficial effects and potential risks of tomato consumption for human health: An overview. Nutrition 2019, 62, 201-208. [CrossRef] [PubMed]

6. Cheng, H.M.; Kotsidis, G.; Lodge, J.K.; Ashor, A.W.; Siervo, M.; Lara, J. Lycopene and tomato and risk of cardiovascular diseases: A systematic review and meta-analysis of epidemiological evidences. Crit. Rev. Food Sci. Nutr. 2019, 59, 141-158. [CrossRef]

7. Vallverdú-Queralt, A.; Rinaldi de Alvarenga, J.F.; Estruch, R.; Lamuela-Raventos, R.M. Bioactive compounds present in the Mediterranean sofrito. Food Chem. 2013, 141, 3365-3372.

8. Martínez-Huelamo, M.; Tulipani, S.; Estruch, R.; Escribano, E.; Ilan, M.; Corella, D.; Lamuela-Raventos, R.M. The tomato sauce making process affect the bioaccessibility and bioavailability of tomato phenolics: A pharmacokinetic study. Food Chem. 2015, 173, 864-872. [CrossRef]

9. Yoshimura, M.; Sano, A.; Kamei, J.I.; Obata, A. Identification and quantification of metabolites of orally administered naringenin chalcone in rats. J. Agric. Food Chem. 2009, 57, 6432-6437. [CrossRef]

10. Mitjavila, M.T.; Moreno, J.J. The effect of polyphenols on oxidative stress and the arachidonic acid cascade. Implications for the prevention/treatment of high prevalence diseases. Biochem. Pharmacol. 2012, 84, 1113-1122. [CrossRef]

11. Rao, A.V. Lycopene, tomatoes, and the prevention of coronary heart disease. Exp. Biol. Med. 2002, 227, 908-913. [CrossRef] [PubMed]

12. Visioli, F.; Riso, P.; Grande, S.; Galli, C.; Porrini, M. Protective action of tomato products in in vivo markers of lipid oxidation. Eur. J. Nutr. 2003, 42, 201-206. [CrossRef] [PubMed]

13. Mulvihill, E.E.; Assini, J.M.; Sutherland, B.G.; DiMattia, A.S.; Khami, M.; Koppes, J.B.; Sawyez, C.G.; Whitman, S.C.; Huff, M.W. Naringenin decreases progression of atherosclerosis by improving dyslipidemia in high-fat-fed low-density lipoprotein receptor-null mice. Arterioscler. Thromb. Vasc. Biol. 2010, 30, 742-748. [CrossRef] [PubMed]

14. Müller, L.; Caris-Veyrat, C.; Lowe, G.; Böhm, V. Lycopene and its antioxidant role in the prevention of cardiovascular diseases-A critical review. Crit. Rev. Food Sci. Nutr. 2016, 56, 1868-1879. [CrossRef] [PubMed] 
15. Steinberg, D. Low density lipoprotein oxidation and its pathobiological significance. J. Biol. Chem. 1997, 272, 20963-20966. [CrossRef] [PubMed]

16. Toshima, S.; Haserawa, A.; Kurabayashi, M.; Itabe, H.; Takano, T.; Sugano, J.; Shimamura, K.; Kimura, J.; Michishita, I.; Suzuki, T.; et al. Circulating oxidized low density lipoprotein levels. A biochemical risk marker for coronary heart disease. Arterioscler. Thromb. Vasc. Biol. 2000, 20, 2243-2247. [CrossRef]

17. Ehara, S.; Vada, M.; Naruko, T. Elevated levels of oxidized low density lipoprotein show a positive relationship with the severity of acute coronary syndromes. Circulation 2001, 103, 1955-1960. [CrossRef] [PubMed]

18. Henrikse, T.; Mahoney, E.M.; Steinberg, D. Enhanced macrophage degradation of low density lipoprotein previously incubated with cultured endothelial cells: Recognition by receptors for the acetylated low density lipoproteins. Proc. Natl. Acad. Sci. USA 1981, 78, 6499-6503. [CrossRef] [PubMed]

19. Osberud, B.; Bjorklid, E. Role of monocytes in atherogenesis. Physiol. Rev. 2003, 83, 1069-1112. [CrossRef]

20. Tsuchiya, S.; Kobayashi, Y.; Goto, Y.; Okumura, H.; Nakae, S.; Konno, T.; Tada, K. Induction of maturation in cultured human monocytic leukemia cells by a phorbol diester. Cancer Res. 1982, 42, 1530-1536.

21. Chung, B.H.; Segrest, J.P.; Ray, M.J.; Brunzell, J.D.; Hokanson, J.E.; Krauss, R.M.; Beaudrie, K.; Cone, J.T. Single vertical spin density gradient ultracentrifugation. Methods Enzymol. 1986, 128, 181-209. [PubMed]

22. Peterson, G.L. A simplification of the protein assay method of Lowry et al. which is more generally applicable. Anal. Biochem. 1977, 83, 346-356. [CrossRef]

23. Esterbauer, H.; Striegl, G.; Puhl, H. Continuous monitoring of in vitro oxidation of human low density lipoprotein. Free Radic. Res. Commun. 1989, 6, 67-75. [CrossRef] [PubMed]

24. Yagi, K. A simple fluorimetric assay for lipoperoxide in blood sample. Biochem. Med. 1976, 15, $212-216$. [CrossRef]

25. Innerarity, T.L.; Pitas, R.E.; Mahley, R.W. Lipoprotein receptor interactions. Methods Enzymol. 1986, 129, 542-565. [PubMed]

26. Beppu, M.; Watanabe, M.; Sunohara, M.; Ohishi, K.; Mishima, E.; Kawashi, H.; Fujii, M.; Kikugawa, K. Participation of the arachidonic acid cascade pathway in macrophage binding/uptake of oxidized low density lipoprotein. Biol. Pharm. Bull. 2002, 25, 710-712. [CrossRef] [PubMed]

27. Moreno, J.J. Effect of olive oil minor components on oxidative stress and arachidonic acid mobilization and metabolism by macrophages RAW 264. Free Radic. Biol. Med. 2003, 35, 1073-1081. [CrossRef]

28. Krieger, M.; Herz, J. Structures and functions of multiligand lipoprotein receptors: Macrophage scavenger receptor and LDL receptor-related protein (LRP). Annu. Rev. Biochem. 1994, 63, 343-346. [CrossRef]

29. Ross, J.A.; Kasum, C.M. Dietary flavonoids: Bioavailability, metabolic effects, and safety. Annu. Rev. Nutr. 2002, 22, 19-34. [CrossRef]

30. Getz, G.S.; Reardon, C.A. Atherogenic lipids and macrophage subsets. Curr. Opin. Lipidol. 2015, 26, 357-361. [CrossRef]

31. Di Pietro, N.; Formoso, G.; Pandolfi, A. Physiology and pathophysiology of oxLDL uptake by vascular wall cells in atherosclerosis. Vascul. Pharmacol. 2016, 84, 1-7. [CrossRef]

32. Sugamura, K.; Keaney, J.F., Jr. Reactive oxygen species in cardiovascular disease. Free Radic. Biol. Med. 2011, 51, 978-992. [CrossRef]

33. Yuhki, K.; Kojima, F.; Kashiwagi, H.; Kawabe, J.; Fujino, T.; Narumiya, S.; Ushikubi, F. Roles of prostanoids in the pathogenesis of cardiovascular diseases: Novel insights from knockout mouse studies. Pharmacol. Ther. 2011, 129, 195-205. [CrossRef]

34. Sies, H.; Stahl, W.; Sundquist, A.R. Antioxidant functions of vitamins. Vitamins E and C, beta-carotene, and other carotenoids. Ann. N. Y. Acad. Sci. 1992, 669, 7-20. [CrossRef]

35. Turk, K.L.; Hayball, R.J. Major phenolic compounds in olive oil: Metabolism and health effects. J. Nutr. Biochem. 2002, 13, 636-644.

36. Cavia-Saiz, M.; Busto, M.D.; Pilar-Izquierdo, M.C.; Ortega, N.; Perez-Mateos, M.; Muñiz, P. Antioxidant properties, radical scavenging activity and biomolecule protection capacity of flavonoid naringenin and its glycoside naringin: A comparative study. J. Sci. Food Agric. 2010, 90, 1238-1244. [CrossRef]

37. Martínez-Huelamo, M.; Vallverdú-Queralt, A.; Di Lecce, G.; Valderas-Martínez, P.; Tulipani, S.; Jáuregui, O.; Escribano-Ferrer, E.; Estruch, R.; Ilán, M.; Lamuela-Raventos, R.M. Bioavailability of tomato polyphenols is enhanced by processing and fat addition: Evidence from a randomized feeding trial. Mol. Nutr. Food Res. 2016, 60, 1578-1589. [CrossRef] 
38. Fuhrman, B.; Volkova, N.; Rosenblat, M.; Aviram, M. Lycopene synergistically inhibits LDL oxidation in combination with vitamin E, glabridin, rosmarinic acid, carnosic acid, or garlic. Antioxid. Redox Signal. 2000, 2, 491-506. [CrossRef]

39. Vivancos, M.; Moreno, J.J. Effect of resveratrol, tyrosol and $\beta$-sitosterol on oxidised low-density lipoprotein-stimulated oxidative stress, arachidonic acid release and prostaglandin $\mathrm{E}_{2}$ synthesis by RAW 264.7 macrophages. Br. J. Nutr. 2008, 99, 1199-1207. [CrossRef]

40. Rahaman, S.O.; Lennon, D.J.; Febbraio, M.; Rodrez, E.A.; Hazen, S.L.; Silverstein, R.L. A CD36-dependent signalling cascade is necessary for macrophage foam cell formation. Cell Metab. 2006, 4, 211-221. [CrossRef]

41. Martinez, J.; Sanchez, T.; Moreno, J.J. Regulation of prostaglandin $\mathrm{E}_{2}$ production by the superoxide radical and nitric oxide in mouse peritoneal macrophages. Free Radic. Res. 2000, 32, 303-311. [CrossRef]

42. Martinez, J.; Moreno, J.J. Role of $\mathrm{Ca}^{2+}$-independent phospholipase $\mathrm{A}_{2}$ on arachidonic acid release induced by reactive oxygen species. Arch. Biochem. Biophys. 2001, 392, 257-262. [CrossRef]

43. Vivancos, M.; Moreno, J.J. Role of $\mathrm{Ca}^{2+}$-independent phospholipase $\mathrm{A}_{2}$ and cyclooxygenase/Lipoxygenase pathways in the nitric oxide production by murine macrophages stimulated by lipopolysaccharides. Nitric Oxide 2002, 6, 255-262. [CrossRef]

44. Lupo, G.; Nicotra, A.; Giurdanella, G.; Anfuso, C.D.; Romeo, L.; Biondi, G.; Tirolo, C.; Marchetti, B.; Ragusa, N.; Alberghina, M. Activation of phospholipase A2 and MAP kinases by oxidized low-density lipoproteins in immortalized GP8.39 endothelial cells. Biochim. Biophys. Acta 2005, 1735, 135-150. [CrossRef]

45. Muroya, T.; Ihara, Y.; Ikeda, S.; Yasuoka, C.; Miyahara, Y.; Urata, Y.; Kondo, T.; Kohno, S. Oxidative modulation of NFkB signaling by oxidized low-density lipoproteins. Biochem. Biophys. Res. Commun. 2003, 309, 900-905. [CrossRef]

46. Kamiloglu, S.; Demirci, M.; Selen, S.; Toydemir, G.; Boyacioglu, D.; Capanoglu, E. Home processing of tomatoes (solanum lycopersicum): Effects on in vitro bioaccessibility of total lycopene, phenolics, flavonoids, and antioxidant capacity. J. Sci. Food Agric. 2014, 94, 2225-2233. [CrossRef]

47. Valderas-Martínez, P.; Chica-Blanch, G.; Casa, R.; Arranz, S.; Martínez-Huelamo, M.; Urpi-Sarda, M.; Torrado, X.; Corella, D.; Lamuela-Raventos, R.M.; Estruch, R. Tomato sauce enriched with olive oil exerts greater effects on cardiovascular disease risk factors than raw tomato and tomato sauce: A randomized trial. Nutrients 2016, 8, 170. [CrossRef]

48. Hiltunen, T.P.; Yla-Herttuala, S. Expression of lipoprotein receptors in atherosclerotic lesions. Atherosclerosis 1998, 137, S81-S88. [CrossRef]

49. Miles, E.A.; Wallace, F.A.; Calder, P.C. An olive oil-rich diet reduces scavenger receptor mRNA in murine macrophages. Br. J. Nutr. 2001, 85, 185-191. [CrossRef]

50. Granados-Principal, S.; Quiles, J.L.; Ramírez-Tortosa, C.L.; Ochoa-Herrera, J.; Perez-Lopez, P.; Pulido-Moran, M.; Ramirez-Tortosa, M.C. Squalene ameliorates atherosclerotic lesions through the reduction of CD36 scavenger receptor expression in macrophages. Mol. Nutr. Food Res. 2012, 56, 733-740. [CrossRef]

51. Storniolo, C.E.; Moreno, J.J. Resveratrol metabolites have an antiproliferative effect on intestinal epithelial cancer cells. Food Chem. 2012, 134, 1385-1391. [CrossRef]

52. Tresserra-Rimbau, A.; Lamuela-Raventos, R.M.; Moreno, J.J. Polyphenols, food and pharma. Current knowledge and directions for future research. Biochem. Pharmacol. 2018, 156, 186-195. [CrossRef]

53. Vilahur, G.; Cubedo, J.; Padró, T.; Casaní, L.; Mendieta, G.; González, A.; Badimon, L. Intake of cooked tomato sauce preserves coronary endothelial function and improves apolipoprotein A-I and apolipoprotein J protein profile in high-density lipoproteins. Transl. Res. 2015, 166, 44-56. [CrossRef]

(C) 2019 by the authors. Licensee MDPI, Basel, Switzerland. This article is an open access article distributed under the terms and conditions of the Creative Commons Attribution (CC BY) license (http://creativecommons.org/licenses/by/4.0/). 